\title{
STRUCTURE TRANSFORMATION OF THE ANURAN AMPHIBIAN SPAWNING COMMUNITIES IN FLOODPLAIN LAKES OF THE MEDVEDITSA RIVER VALLEY (SARATOV REGION) UNDER CONDITIONS OF LONG-TERM REDUCTION OF WATER CONTENT
}

\author{
Mikhail V. Yermokhin ${ }^{1}$, Gleb A. Ivanov ${ }^{1}$, and Vasily G. Tabachishin ${ }^{2}$ \\ ${ }^{1}$ Saratov State University \\ 83 Astrakhanskaya Str., Saratov 410012, Russia \\ E-mail:ecoton@rambler.ru \\ ${ }^{2}$ Saratov branch of A. N. Severtsov Institute of Ecology and Evolution, \\ Russian Academy of Sciences \\ 24 Rabochaya Str., Saratov 410028, Russia \\ E-mail: tabachishinvg@sevin.ru
}

Received 12 September 2018, revised 21 October 2018, accepted 29 October 2018

\begin{abstract}
Yermokhin M. V., Ivanov G. A., Tabachishin V. G. Structure Transformation of the Anuran Amphibian Spawning Communities in Floodplain Lakes of the Medveditsa River Valley (Saratov Region) under Conditions of Long-Term Reduction of Water Content. Povolzhskiy Journal of Ecology, 2018, no. 4, pp. 404- 417 (in Russian). DOI: https://doi.org/10.18500/1684-7318-2018-4-404-417
\end{abstract}

The structure of spawning taxocenoses of anuran amphibians in five floodplain lakes of the Medveditsa river valley in 2009-2018 is analysed. Two near-terrace lakes (Lebyazhye and Koblovo) and three lakes of the central floodplain (Sadok, Kruglen'koye, and Cherepashie) were used as model ones. The degradation of the populations of the three most numerous species, a decrease in the dominance degree of the common spadefoot toad were established. Degradation is more characteristic of species with a longerer distance of spawning migrations - the severity of changes consistently decreases in the row of species: Pelophylax ridibundus $\rightarrow$ Pelobates fuscus $\rightarrow$ Bombina bombina. Indices of the structure of amphibian communities in the near-terrace lakes Lebyazhye and Koblovo were stable. Against the background of low water content and unstable hydrological regime of the central floodplain lakes with a survey duration of five or more years, three periods were established to characterize the structure of spawning amphibian taxocenoses, namely: a stable structure, a sharp decrease in dominance and an increase in evenness, and an increase in the variability of the main attributes of the structure. At the end of the third period, which characterizes the structure of taxocenoses, some stabilization of the main parameters was noted with an extremely low number of mature individuals of all amphibian species. The high level of spring flood of the Medveditsa river in 2018 determined the beginning of the exit from the abnormally long period of low water content of the spawning lakes in the floodplain (from 2009 till 2017) and their functioning in the hydrological regime as temporary water bodies. The sudden increase in water content of the floodplain lakes and the extension of their hydroperiod allow the beginning of the recovery process of the population size and community structure of anuran amphibians to be noted.

Key words: Anura, Pelophylax ridibundus, Pelobates fuscus, Bombina bombina, spawning taxocenosis.

DOI: https://doi.org/10.18500/1684-7318-2018-4-404-417

\section{INTRODUCTION}

Anuran amphibians are the most numerous group of terrestrial and amphibiotic vertebrates in river valleys (Shlyakhtin et al., 2014, 2015). They have a significant impact 


\section{STRUCTURE TRANSFORMATION OF THE ANURAN AMPHIBIAN}

on the structure and functioning of terrestrial and aquatic ecosystems, form a system of matter and energy flows across the water-land boundary (Yermokhin, 2014). The complex of morphological and functional features of the anuran amphibians determines their vulnerability to changes in climatic conditions (Gardner, 2001; Carey, Alexander, 2003; Nyström et al., 2007; Wells, 2007; Todd et al., 2011) associated with warming and water loss in terrestrial habitats. However, despite the already established set of main causes for the decline in the numbers of amphibians in the temperate latitudes, most of them are not universal and are more likely to be local in nature (Grant et al., 2016). Therefore, to determine the real causes of the degradation of amphibian populations, it becomes relevant to conduct long-term studies in a particular region.

Under the conditions of the long-term tendency to decrease in water content in the river valleys of the Don basin, which has been continuing since the 1990s, the flood regime of rivers degrades (Yermokhin, 2000; Kireeva, 2013). Frequent flooding leads to a reduction in the area, hydroperiod and mass drying up of floodplain reservoirs, deprived of feeding with flood waters. Meanwhile, the duration of the hydroperiod of spawning reservoirs is considered one of the most important factors determining the status of populations, the species richness and structure of anuran amphibian communities (Pechmann et al., 1989; Snodgrass et al., 2000; McMenamin et al., 2008; Church, 2008; Blaustein et al., 2010; Hossack, 2017). The dynamism of quantitative attributes of anuran amphibian populations that can influence the structure of their communities has been noted in many regions of Europe (Bonk, Pabijan, 2010; Antonyuk, Panchenko, 2017). However, to date, studies of the structure of anuran amphibian taxocenoses on spawning places remain relatively few (Lizana et al., 1990; Semlitsch et al., 1996; Skelly et al., 1999; Ficetola, Bernardi, 2004; Gray et al., 2004; Leite-Filho et al., 2017). At the same time, such studies are relevant for monitoring their status and for timely organizing necessary environmental protection measures.

The purpose of this paper was a comparative analysis of the structure of spawning taxocenoses of anuran amphibians in the period of a decreased water content in floodplain lakes in the ecosystems of the Medveditsa river valley.

\section{MATERIAL AND METHODS}

Taxocenoses of anuran amphibians were surveyed in the valley of the middle reaches of the Medveditsa river (the vicinities of the village Uritskoe, Lysogorsky district, Saratov region) in 2009-2018. The following floodplain lakes were used as model

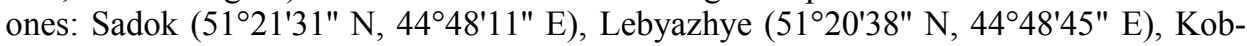

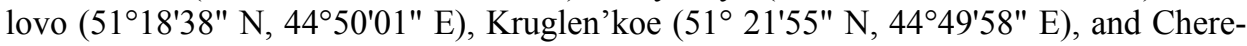
pashie $\left(51^{\circ} 21^{\prime} 52^{\prime \prime} \mathrm{N}, 44^{\circ} 49^{\prime} 05^{\prime \prime} \mathrm{E}\right)$. Detailed characteristics of these model reservoirs were given earlier (Yermokhin, Tabachishin, $2011 a$; Ivanov, 2017). Counts were carried out using the method of linear fences with trap cylinders (Yermokhin, Tabachishin, 2011 b; Yermokhin et al., 2012) during the spawning migrations (from the last decade of March to the end of May) (Yermokhin et al., 2013). Pelobates fuscus in the study region began spawning migrations before the other species of anuran amphibians. The beginning of this phenological phenomenon was associated with the water temperature in the spawning reservoir and that in the soil at the wintering depth approaching $+4.5^{\circ} \mathrm{C}$ (Yer- 
mokhin et al., 2015), and these values coincided. To obtain unbiased estimates of the abundance of this most widespread amphibian species, it was necessary to correctly determine the time of the start of spawning migrations. Therefore, our choice of the threshold value of the water temperature in the spawning reservoir was due to thermobiological features of this particular species. The installation date of linear fences was calculated from the dynamics of the seasonal variation of temperature, based on the data of weather forecasts (Yermokhin et al., 2017), when the average air temperature during 10 days was approaching this threshold value. With such an approach, the deviation of the estimated start date of spawning migrations from the actual one did not exceed 3 days during 2009-2018. Therefore, the fences were installed three days before the onset of this phenomenon. The end of spawning migrations was considered the period of 10 days after the arrival of the last mature individuals of amphibians to the reservoirs.

The abundance of three numerous species of anuran amphibians was estimated, namely: Pelobates fuscus (Laurenti, 1768) (the eastern form of this species lives in the research region (Polukonova et al., $2013 a, b)$ ), Bombina bombina (Linnaeus, 1761) and Pelophylax ridibundus (Pallas, 1771). The volume of research material for various spawning lakes is given in Table 1. Other amphibian species (Rana arvalis Nilsson, 1842 and Lissotriton vulgaris (Linnaeus, 1758)) had a low level of population numbers, were encountered sporadically, not annually, and not on all the lakes surveyed. Obviously, their populations were in a status close to complete degradation, and provided no sustainable reproduction.

Table 1. Numbers of anuran amphibian specimens spawning in several floodplain lakes in 2009-2018

\begin{tabular}{|c|c|c|c|c|}
\hline \multirow{2}{*}{ Year } & \multicolumn{3}{|c|}{ Species } & \multirow{2}{*}{ Total } \\
\hline & Pelobates fuscus & Pelophylax ridibundus & Bombina bombina & \\
\hline 1 & 2 & 3 & 4 & 5 \\
\hline \multicolumn{5}{|c|}{ Lake Lebyazhie } \\
\hline 2009 & 667 & 2 & 9 & 678 \\
\hline 2010 & 657 & 6 & 4 & 667 \\
\hline 2013 & 651 & 7 & 6 & 664 \\
\hline \multicolumn{5}{|c|}{ Lake Koblovo } \\
\hline 2010 & 121 & 12 & 5 & 138 \\
\hline 2011 & 108 & 8 & 4 & 120 \\
\hline \multicolumn{5}{|c|}{ Lake Sadok } \\
\hline 2010 & 945 & 16 & 7 & 968 \\
\hline 2011 & 928 & 312 & 20 & 1260 \\
\hline 2012 & 786 & 295 & 18 & 1099 \\
\hline 2013 & 831 & 276 & 15 & 1122 \\
\hline 2014 & 329 & 124 & 4 & 457 \\
\hline 2015 & 124 & 97 & 9 & 230 \\
\hline 2016 & 53 & 6 & 2 & 61 \\
\hline 2017 & 35 & 3 & 0 & 38 \\
\hline 2018 & 25 & 2 & 0 & 27 \\
\hline \multicolumn{5}{|c|}{ Lake Kruglen'koe } \\
\hline 2013 & 1352 & 13 & 72 & 1437 \\
\hline 2014 & 408 & 28 & 137 & 573 \\
\hline
\end{tabular}


STRUCTURE TRANSFORMATION OF THE ANURAN AMPHIBIAN

Table 1. Continuation

\begin{tabular}{c|c|c|c|c}
\hline 1 & 2 & 3 & 4 & 5 \\
\hline 2015 & 197 & 8 & 139 & 344 \\
\hline 2016 & 59 & 3 & 44 & 106 \\
\hline 2017 & 35 & 0 & 5 & 40 \\
\hline 2018 & 41 & 5 & 6 & 52 \\
\hline \multicolumn{5}{l}{} \\
\hline 2014 & 1157 & Lake Cherepashie & 180 & 1358 \\
\hline 2015 & 916 & 21 & 177 & 1033 \\
\hline 2016 & 286 & 0 & 61 & 347 \\
\hline 2017 & 228 & 0 & 8 & 240 \\
\hline 2018 & 39 & 4 & 4 & 47 \\
\end{tabular}

The significance of differences in the ratio of species that spawned in different years in a particular reservoir was estimated using contingency tables $\left(\chi^{2}\right.$ test). Differences were considered significant when $P<0.05$. The consistency of variation of the degree of reduction in the numbers of species with a range of migration from their wintering sites to their spawning places was assessed using Spearman's rank correlation coefficient $\left(r_{s}\right)$. For the spawning reservoirs studied for three or more years, a periodization procedure was carried out on the basis of cluster analysis (Ward's algorithm, Euclidean distance), grouping, for further analysis, years similar in the numbers of individual species. Our processing of the material included the calculation of the following indicators characterizing the structure of taxocenoses: dominance indices $(D)$, Shannon $(H)$ and Berger-Parker indices $(d)$. Within the selected periods for each of the listed indices, the mean value, standard deviation, and range of variation ( $\min -\max$ ) were calculated. To process the collected material, initial sample data were used, obtained when counting anuran amphibians, including the incomplete enclosing of spawning reservoirs with fences, with no recalculation to the absolute numbers of individuals spawning therein. Statistical data processing was performed in the PAST 2.17 software package.

\section{RESULTS}

$P$. fuscus was the predominant species of anuran amphibians during the entire period of survey in all reservoirs. The trends in the populations of this species were most noticeable in the central floodplain lakes, where significant degradation of $P$. fuscus populations occurs. This species, even against the background of abundance reduction, was tens of times more quantitative than other species of anuran amphibians (P. ridibundus and B. bombina). The status of the populations of these semi-aquatic species in the structure of spawning taxocenoses was determined by the degree of remoteness of their spawning reservoir from the riverbed. P. ridibundus reached the highest numbers in the lake Sadok, closest to the wintering places in the Medveditsa riverbed. The smallest abundance was noted in the near-terrace lakes, at distances from $0.6 \mathrm{~km}$ (Lake Koblovo) to $1.1 \mathrm{~km}$ (Lake Lebyazhye) from the riverbed.

The ratio of anuran amphibian species in their spawning taxosenoses was more stable for many years in the near-terrace lakes Lebyazhie and Koblovo $\left(\chi^{2}\right.$ test, $P>0.31$ ) and underwent significant changes in the central floodplain lakes (Sadok, Kruglen'koe, 
and Cherepashie; $\chi^{2}$ test, $P<0.0001$ ) (Table 2). For the ratio of the amphibian species spawning in these three lakes, interannual differences were found over a number of pairs of adjacent years of survey.

Table 2. Ratio of species in spawning taxocenoses of anuran amphibians

\begin{tabular}{|c|c|c|c|}
\hline \multirow{2}{*}{ Lake } & \multirow{2}{*}{$\frac{\chi^{2}}{P}$} & \multicolumn{2}{|c|}{ Pair differences } \\
\hline & & existed & were absent \\
\hline Lebyazhie & $\underline{4.81}$ & - & 2009-2010, 2010-2013 \\
\hline Sadok & $\frac{373.14}{<0.0001}$ & $\begin{array}{c}2010-2011,2014- \\
2015,2015-2016\end{array}$ & $\begin{array}{c}\text { 2011-2012, 2012-2013, } \\
2013-2014,2016-2017 \text {, } \\
\text { 2017-2018 }\end{array}$ \\
\hline Kruglen'koe & $\frac{418.72}{<0.0001}$ & $\begin{array}{c}2013-2014,2014- \\
2015,2016-2017\end{array}$ & 2015-2016, 2017-2018 \\
\hline Cherepashie & $<\frac{76.90}{<0.0001}$ & $\begin{array}{c}2014-2015,2015- \\
2016,2016-2017, \\
2017-2018\end{array}$ & - \\
\hline Koblovo & $\frac{0.40}{0.82}$ & - & 2010-2011 \\
\hline
\end{tabular}

Note. The significance level $(P<0.05)$ is marked bold.

During 2010, the abundance of $P$. ridibundus in the spawning places of lake Sadok was abnormally low compared with the next five years. During 2011-2015 it remained relatively stable with a further strengthening downtrend, which led to the almost complete degradation of their local populations in 2016-2018.

Our comparative analysis of the variability in the abundance of the three amphibian species showed that it was more stable in the near-terrace lakes Lebyazhie and Koblovo (P. fuscus: $C V=1.22$ and 8.03, respectively; $P$. ridibundus: $C V=52.92$ and 28.28; $B$. bombina: $C V=39.74$ and 15.71). The variability was lower in the species wintered in terrestrial biotopes near their spawning reservoirs (P. fuscus and B. bombina), and significantly higher in $P$. ridibundus with distant spawning migrations. At the same time, for the populations spawning in the central floodplain lakes, significantly higher directed population changes were observed ( $P$. fuscus: $C V=92-147 \%, 110 \%$ on average; $P$. ridibundus: $C V=106-151,121$ on average; $B$. bombina: $C V=87-101,93$ on average). The population variability degree decreased consistently with a decrease in the range of spawning migrations (Blab, 1986; Kovar et al., 2009) in the three species of anuran amphibians, forming the series: $P$. ridibundus $\rightarrow P$. fuscus $\rightarrow B$. bombina.

$P$. ridibundus was characterized by the most distant migrations in the Medveditsa river valley. This species inhabited spawning lakes remote from the nearest wintering habitats in the riverbed for a distance up to $4.5 \mathrm{~km}$. The number of $P$. ridibundus individuals regularly decreased with the distance of the spawning reservoir from the riverbed (Spearman's rank correlation coefficient: $\left.r_{s}=-0.60, P=0.007\right)$. And on the spawning places in the most remote floodplain lakes (Lake Cherepashie), there was almost complete degradation of the $P$. ridibundus populations by 2018 (Table 1). 
For another semi-aquatic species of anuran amphibians, B. bombina, the remoteness of its spawning lake from the riverbed could also influence the degree of development of the populations. There was a consistent variation in the numbers of mature individuals participated in breeding with this indicator $\left(r_{s}=0.87, P<0.0001\right)$.

The smallest degree of the impact of the spawning reservoir position in the floodplain was found in the species most adapted to habitat in terrestrial biotopes, $P$. fuscus $\left(r_{s}=0.16, P=0.59\right)$.

The structure dynamics of spawning groups of anuran amphibians differed in lakes with different positions in the floodplain. E.g., the near-terrace lakes had relatively stable indicators of structure for a number of years, while the central floodplain lakes, on the contrary, underwent certain dynamic changes of these indicators under the conditions of the current period of low water content (Table 3).

Table 3. Structure dynamics of anuran amphibian taxocenoses during their spawning migrations on several lakes of the Medveditsa river valley

\begin{tabular}{|c|c|c|c|c|}
\hline \multirow{2}{*}{ Lake } & \multirow{2}{*}{ Periods } & \multicolumn{3}{|c|}{ Indices } \\
\hline & & $D$ & $H$, bit/specimen & $d$ \\
\hline \multicolumn{5}{|c|}{ Near-terrace lakes } \\
\hline Lebyazhie & $2009,2010,2013$ & $\frac{0.97 \pm 0.004}{0.96-0.97}$ & $\frac{0.10 \pm 0.01}{0.09-0.11}$ & $\frac{0.98 \pm 0.002}{0.98-0.99}$ \\
\hline Koblovo & $2010-2011$ & $\underline{0.80 \pm 0.03}$ & $\frac{0.42 \pm 0.04}{0.39-0.45}$ & $\frac{0.89 \pm 0.02}{0.88-0.90}$ \\
\hline \multicolumn{5}{|c|}{ Central floodplain lakes } \\
\hline \multirow{4}{*}{ Sadok } & 2010 & 0.95 & 0.13 & 0.98 \\
\hline & 2011-2013 & $\frac{0.60 \pm 0.01}{0.58-0.61}$ & $\frac{0.64 \pm 0.02}{0.63-0.66}$ & $\frac{0.73 \pm 0.01}{0.72-0.74}$ \\
\hline & 2014-2018 & $\frac{0.71 \pm 0.17}{0.47-0.86}$ & $\frac{0.49 \pm 0.24}{0.26-0.82}$ & $\frac{0.79 \pm 0.17}{0.54-0.93}$ \\
\hline & In particular, 2016-2018 & $\frac{0.83 \pm 0.05}{0.77-0.86}$ & $\frac{0.33 \pm 0.11}{0.26-0.46}$ & $\frac{0.91 \pm 0.03}{0.87-0.93}$ \\
\hline \multirow{3}{*}{ Kruglen'koe } & 2013 & 0.89 & 0.25 & 0.94 \\
\hline & 2014-2018 & $\frac{0.59 \pm 0.12}{0.48-0.78}$ & $\begin{array}{l}0.67 \pm 0.17 \\
0.38-0.79\end{array}$ & $\frac{0.70 \pm 0.14}{0.56-0.88}$ \\
\hline & In particular, 2016-2018 & $\frac{0.71 \pm 0.10}{0.64-0.78}$ & $\frac{0.52 \pm 0.20}{0.38-0.66}$ & $\frac{0.83 \pm 0.06}{0.79-0.88}$ \\
\hline \multirow{2}{*}{ Cherepashie } & $2014-2015$ & $\frac{0.77 \pm 0.04}{0.74-0.80}$ & $\frac{0.41 \pm 0.08}{0.35-0.47}$ & $\frac{0.87 \pm 0.02}{0.85-0.89}$ \\
\hline & 2016-2018 & $\frac{0.77 \pm 0.11}{0.70-0.90}$ & $\frac{0.42 \pm 0.18}{0.23-0.57}$ & $\frac{0.87 \pm 0.07}{0.82-0.95}$ \\
\hline
\end{tabular}

Analysis of the results of abundance counts on spawning reservoirs, surveyed for a long time (longer than three years), has allowed us to identify a number of periods characterizing different statuses of spawning taxocenoses of anuran amphibians (Figure). E.g., on the lake Sadok, three distinct periods of the existence of these groups was noted: 2010, 2011-2013, and 2014-2018; on the lake Kruglen'koe there were two periods: 2013 and 2014-2018. The presence of such periods is due to, above all, the significant transformation of the hydrological regime of spawning reservoirs in the floodplain against the background of the transformation of the flood regime of the Medveditsa 
River associated with the sharp climate aridization in 2009-2011 and the decreased water content of the spawning lakes.
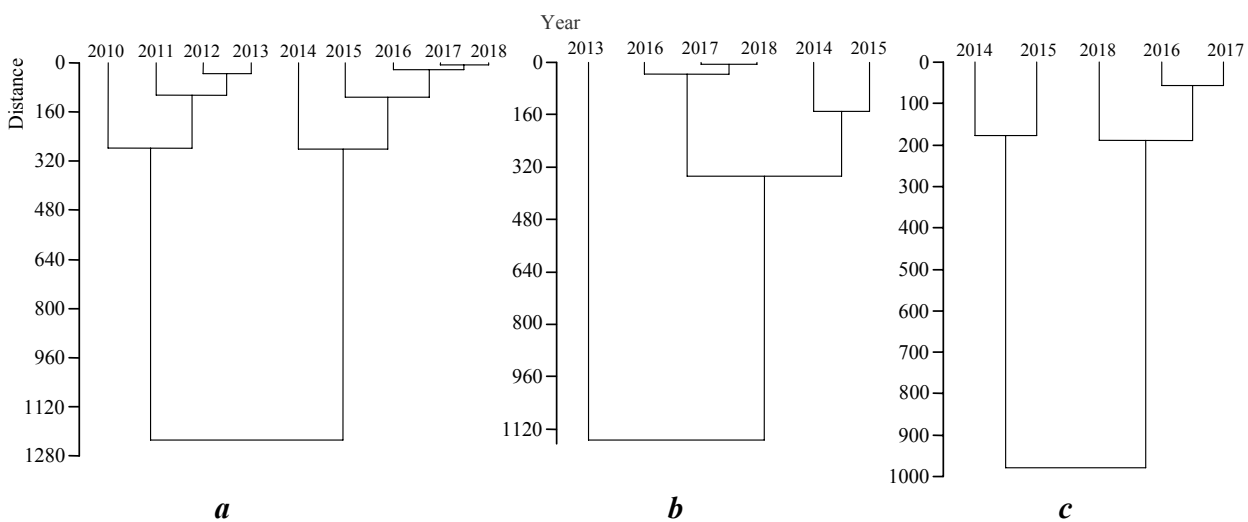

Figure. Periodization of the structure of spawning taxocenoses of anuran amphibians in the lakes of the central floodplain of the Medveditsa River: Sadok (a), Kruglen'koe (b), and Cherepashie (c) (cluster analysis, Euclidean distance, Ward algorithm)

In 2010, the groups of amphibians in the lake Sadok were characterized by a particularly high level of domination of one species (P. fuscus), which was comparable to that in the near-terrace lakes during a similar period. However, later there was a sharp change in the set of indicators characterizing the equalization and dominance in spawning groups. The period of time during which such changes took place is clearly divided into two stages. During the first stage (2011-2013) a more aligned character of the grouping was settled (Table 3), which was due to the decrease in the population of the dominant $P$. fuscus against the background of the increase in the number of the second most important species, $P$. ridibundus. It should also be noted that during these three years the level of the indicators characterizing the structure of the amphibian taxocenosis was relatively stable $(D: C V=2.24 ; H: C V=2.79 ; d: C V=1.86)$. At the second stage of transformation of the amphibian taxocenosis structure (2014-2018), while maintaining a similar degree of equalization and dominance (Table 3 ), there was a sharp increase in the variability of these main indicators $(D: C V=24 ; H: C V=49 ; d: C V=21)$.

In the spawning taxocenosis of amphibians in the lake Kruglen'koe, processes with similar characteristics were observed: by 2014-2018, with a decrease in the role of the dominant species, a level of quantitative values of the indices of dominance and equalization was settled which was identical to the taxocenosis of the lake Sadok (Table 3). Although the variability of these indices was generally lower than in the lake Sadok in the same years $(D: C V=21 ; H: C V=25 ; d: C V=20)$. However, it should be noted that the variability in the Shannon diversity index increased by the end of this period (20172018) $(C V=39 \%)$

The quantitative characteristics of the spawning taxocenosis of amphibians in the lake Cherepashie, similar in topological features to the other two lakes in the central floodplain, had a more stable level (Table 3). However, the degree of equalization of the 
taxocenosis was closer to that in the near-terrace lakes and was more stable by variability, in contrast to the lakes Cherepashie and Sadok.

\section{DISCUSSION}

In 2009-2017 there was a significant degradation of the system of floodplain lakes in the valley of the river Medveditsa. The reduction of the hydroperiod of these spawning reservoirs of anuran amphibians leads to the impossibility of completing the development of tadpoles until the lake basins are completely dry. Given the current hydrological situation, which characterizes the floodplain lakes for a sufficiently long period of time, it is necessary to state a significant decrease in the quantitative indicators of the populations of practically all anuran amphibian species. The decrease in the number of floodplain reservoirs during the spawning migrations and, especially, during the migration of fingerlings in the second half of summer leads to the complication of the conditions of transit movements of anuran amphibians between their spawning reservoirs and wintering biotopes. Such changes most negatively affect the status of the $P$. ridibundus populations, which are forced to make long-distance migrations from the near-terrace lakes and the most remote lakes of the central floodplain to the Medveditsa riverbed. If it is impossible to replenish the water reserves in the body during this period, conditions are created for increased mortality of fingerlings and mature individuals of this species. Therefore, the greatest degree of degradation of $P$. ridibundus populations is characteristic, first of all, for the reservoirs located far from the riverbed in the floodplain.

In addition, the high level of variability in the numbers of $P$. ridibundus at the spawning places of the lake Sadok may be due to the change in the migration trajectory of this species during the abnormally hot and dry spring of 2010. The preferential trajectory of the $P$. ridibundus individuals from their wintering biotope (the Medveditsa riverbed) may well be determined by the effect of pioneer males who left their odor trail on the ground along the route. In the period from May 1 to May 12, when P. ridibundus spawning migrations took place, the relative humidity of air at night was on average $48 \%$. In such conditions of low air humidity during a period of prolonged drought, there may be a violation of the conditions for the long-term odor preservation on the surface of the substrate. The importance of the olfactory factor in the orientation of anuran amphibians during their migration to the spawning reservoir was previously shown, including an example of $P$. ridibundus (Babenko et al., 1973). In the above-described weather conditions, the efficiency of preservation, transmission, and perception of the smell signal by amphibians is obviously greatly reduced. Therefore, the movement of individuals of this species occurs not along a channeled route (following the tracks of the first males), but on a broad front, in whose range the distribution of them is more uniform.

In $P$. fuscus, the degradation of populations is primarily determined by the duration of the larval development period and the drying of spawning reservoirs before its completion. The loss of the generations appearing in dry years from populations leads to a reduction in the numbers of mature individuals taking part in reproduction.

The low degree of influence of the position factor of the spawning reservoir in the floodplain on $P$. fuscus spawning populations is due, on the one hand, to the presence of a complex of physiological and behavioral adaptations that allow this species to survive 
long periods with low relative humidity. On the other hand, P. fuscus has a more complex age structure, including up to 16 age groups (Rot-Nikčević et al., 2001), whereas the semi-aquatic $P$. ridibundus and B. bombina species in different parts of their range have no more than 5-6 age groups (Cogălniceanu, Miaud, 2003; Yilmaz et al., 2005; Kyriakopoulou-Sklavounou et al., 2008; Ashkavandi et al., 2012; Zhelev et al., 2014; Ivanova, 2017). Such features allow P. fuscus to survive for a longer time the unfavorable conditions of reproduction associated with the drying up of its spawning reservoirs until the end of tadpole metamorphosis. However, the low-water phase of the 36-38-year Brickner water cycle, characteristic of regions with a continental climate (Shnitnikov, 1950), lasts much longer at the beginning of the $21^{\text {st }}$ century than was typical for similar periods in the previous century. Therefore, during 2010-2017, against the background of significant changes in the size, weight and sex structure (Yermokhin et al., 2016) the degradation of many local populations even of this terrestrial species is possible.

In the spring of 2018, an abnormally high level of water uplift in the Medveditsa river during the flood period was observed, which was $922 \mathrm{~cm}$ from zero on the graph (the third highest water rise in the flood in the last 40 years). This gives grounds to assume that the minimum of the water content of the Brickner cycle has been passed and a phase of steady growth of the water content of the spawning lakes in the Medveditsa river floodplain begins, which could lead to restoration of the population size and structure of amphibian communities.

The change in the status of the dominant species population in all the water bodies surveyed leads to an increase in taxocenosis evenness and a decrease in dominance. Such changes are usually associated with the improvement of the status of the community and its stabilization (Megarran, 1992). Under conditions of long-lasting disturbances of the hydrological regime of the floodplain lakes, which are key to the existence of spawning taxocenoses of anuran amphibians, an obvious degradation of their populations occurs. Therefore, the observed features of the taxocenosis structure dynamics look very contradictory and require additional research.

\section{Acknowledgements}

This work was partially supported by the Russian Foundation for Basic Research (project no. 16-04-01248) and the planned research topic (project no. 0109-2018-00010).

\section{REFERENCES}

Antonyuk E. V., Panchenko I. M. Influence of the hydrological regime of the river Oka on the state of the fauna of amphibians in the Oka reserve. Samarskaya Luka: Problems of Regional and Global Ecology, 2017, vol. 26, no. 3, pp. 121-126 (in Russian).

Ashkavandi S., Gharzi A., Abbassi M. Age determination by skeletochronology Rana ridibunda (Anura: Amphibia). Asian J. Experimental Biol. Science, 2012, vol. 3, no. 1, pp. 156-162.

Babenko L. A., Pashchenko Yu. I., Lyalyushko D. M. Role of Sense Organs in Orientation "by Homing" in Constant-Water Amphibians. Vestnik Zoologii, 1973, no. 2, pp. 30-32 (in Russian).

Blab J. Biologie, Ökologie und Schutz von Amphibien. Schriftenreihe für Landschaftsplege und Naturschutz. Bonn, Kilda Verlag, 1986, Bd. 18. 150 S. 


\section{STRUCTURE TRANSFORMATION OF THE ANURAN AMPHIBIAN}

Blaustein A. R., Walls S. C., Bancroft B. A., Lawler J. J., Searle C. L., Gervasi S. S. Direct and Indirect Effects of Climate Change on Amphibian Populations. Diversity, 2010, vol. 2, no. 2, pp. 281-313.

Bonk M., Pabijan M. Changes in a Regional Ba-trachofauna in South-Central Poland over a 25 year period. North Western J. of Zoology, 2010, vol. 6, no. 2, pp. 225-244.

Carey C., Alexander M. A. Climate change and amphibian declines: is there a link? Diversity and Distributions, 2003, vol. 9, no. 2, pp. 111-121.

Church D. R. Role of Current Versus Historical Hydrology in Amphibian Species Turnover within Local Pond Communities. Copeia, 2008, vol. 2008, no. 1, pp. 115-125.

Cogălniceanu D., Miaud C. Population age structure and growth in four syntopic amphibian species inhabiting a large river floodplain. Canadian J. of Zoology, 2003, vol. 81, no. 6, pp. 10961106.

Ficetola F. G., Bernardi F. de. Amphibians in a human-dominated landscape: the community structure is related to habitat features and isolation. Biological Conservation, 2004, vol. 119, no. 2, pp. 219-230.

Gardner T. Declining Amphibian Populations: a Global Phenomenon in Conservation Biology. Animal Biodiversity and Conservation, 2001, vol. 24, no. 2, pp. 25-44.

Grant E. H. C., Miller D. A. W., Schmidt B. R., Adams M. J., Amburgey S. M., Chambert T., Cruickshank S. S., Fisher R. N., Green D. M., Hossack B. R., Johnson P. T. J., Joseph M. B., Rittenhouse T. A. G., Ryan M. E., Waddle J. H., Walls S. C., Bailey L. L., Fellers G. M., Gorman T. A., Ray A. M., Pilliod D. S., Price S. J., Saenz D., Sadinski W., Muths E. Quantitative evidence for the effects of multiple drivers on continental-scale amphibian declines. Scientific Reports, 2016, vol. 6, pp. 25625. DOI: 10.1038/srep25625

Gray M. J., Smith L. M., Leyva R. I. Influence of agricultural landscape structure on a Southern High Plains, USA, amphibian assemblage. Landscape Ecology, 2004, vol. 19, no. 7, pp. 719-729.

Hossack B. R. Amphibian dynamics in constructed ponds on a wildlife refuge: developing expected responses to hydrological restoration. Hydrobiologia, 2017, vol. 790, no. 1, pp. 23-33.

Ivanov G. A. Reproduktivnaya ekologiya beskhvostykh amfibiy $v$ doline r. Medveditsy (Saratovskaya oblast) [Reproductive Ecology of Anuran Amphibians in Medveditsa River valley (Saratov Region)]. Diss. Cand. Sci. (Biol.). Togliatti, 2017. 171 p. (in Russian).

Ivanova N. L. Growth characteristics and rates of the mash frog Pelophylax ridibundus Pall. introduced into water bodies of the Middle Urals. Biology Bulletin, 2017, vol. 44, no. 4, pp. 412-416.

Kireeva M. B. Vodnyy rezhim rek basseyna Dona $v$ usloviyakh menyayushchegosya klimata [Water regime of Don basin rivers in climate change conditions]. Diss. Cand. Sci. (Geogr.). Moscow, 2013. 211 p. (in Russian).

Kovar R., Brabec M., Vita R., Bocek R. Spring migration distances of some Central European amphibian species. Amphibia - Reptilia, 2009, vol. 30, no. 10, pp. 367-378.

Kyriakopoulou-Sklavounou P., Stylianou P., Tsiora A. A skeletochronological study of age, growth and longevity in a population of the frog Rana ridibunda from southern Europe. Zoology, 2008, vol. 111, no. 1, pp. 30-36.

Leite-Filho E., Oliveira F. A. de, Eloi F. J., Liberal C. N., Lopes A. O., Mesquita D. O. Evolutionary and Ecological Factors Influencing an Anuran Community Structure in an Atlantic Rainforest Urban Fragment. Copeia, 2017, vol. 105, no. 1, pp. 64-74.

Lizana M., Perez-Mellado V., Ciudad M. J. Analysis of the structure of an amphibiam community in the central system of Spain. Herpetological J., 1990, vol. 1, pp. 435-446.

McMenamin S. K., Hadley E. A., Wright C. K. Climatic change and wetland desiccation cause amphibian decline in Yellowstone National Park. Proceedings of the National Academy of Sciences of the USA, 2008, vol. 105, no. 44, pp. 16988-16993. 
Mikhail V. Yermokhin, Gleb A. Ivanov, Vasily G. Tabachishin

Megarran E. Ecological Diversity and its Measurement. Moscow, Mir Publ., 1992. 162 p. (in Russian).

Nyström P., Hansson J., Månsson J., Sundstedt M., Reslow C., Broström A. A documented amphibian decline over 40 years: Possible causes and implications for species recovery. Biological Conservation, 2007, vol. 138, no. 3-4, pp. 399-411.

Pechmann J. H. K., Scott D. E., Gibbons J. W., Semlitch R. Influence of wetland hydroperiod on diversity and abundance of metamorphosing juvenile amphibians. Wetlands Ecology and Management, 1989, vol. 1, no. 1, pp. 3-11.

Polukonova A. V., Djomin A. G., Yermokhin M. V., Tabachishin V. G. New Gaplotypes of Spadefoot Toad Pelobates fuscus (Laurenti, 1768) from Populations in Medveditsa River Valley (Saratov District). Inland Water Biology. Proceedings XV School-Conference of Young Scientists. Kostroma, Kostromskoy pechatny dom, 2013 a, pp. 304-308 (in Russian).

Polukonova A. V., Djomin A. G., Yermokhin M. V., Tabachishin V. G. A Molecular-Genetic Study of Spadefoot Toad Pelobates fuscus (Laurenti, 1768) Local Populations from the Medveditsa River Valley (Saratov Region) by mtDNA - CytB gene. Current Studies in Herpetology, 2013 b, vol. 13, iss. 3-4, pp. 117-121 (in Russian).

Rot-Nikčević I., Sidorovska V., Džukić G., Kalezić M. L. Sexual size dimorphism and life history traits of two european spadefoot toads (Pelobates fuscus and P. syriacus) in allopatry and sympatry. Annales, Ser. Historia Naturalis, 2001, vol. 11, no. 1, pp. 107-120.

Schlyakhtin G. V., Tabachishin V. G., Yermokhin M. V. History and Main Directions of Herpetofauna Investigations at Northern Part of Lower Volga Region (to 105-year of Department of Animal Morphology and Ecology of Saratov State University). Current Studies in Herpetology, 2014, vol. 14, iss. 3-4, pp. 137-146 (in Russian).

Semlitsch R. D., Scott D. E., Pechmann J. H., Gibbons J. W. Structure and Dynamics of an Amphibian Community. In: Long-Term Studies of Vertebrate Communities. San Diego, Academic Press, 1996, pp. 217-248.

Shlyakhtin G. V., Tabachishin V. G., Kaybeleva E. I., Mosolova E. Yu., Yermokhin M. V. Current Status of the Batrachological Collection of the Zoological Museum of Saratov University. Current Studies in Herpetology, 2015, vol. 15, iss. 3-4, pp. 153-159 (in Russian).

Shnitnikov A. V. Intrasecular fluctuations in the level of steppe lakes of Western Siberia and Northern Kazakhstan and their dependence on climate. Transactions of the Laboratory of Limnology, USSR Academy of Sciences. Moscow, 1950, vol. 1, pp. 28-129 (in Russian).

Skelly D. K., Werner E. E., Cortwright S. A. Long-Term Distributional Dynamics of a Michigan Amphibian Assemblage. Ecology, 1999, vol. 80, no. 7, pp. 2326-2337.

Snodgrass J. W., Komoroski M. J., Bryan A. L., Burger J. Relationships among isolated wetland size, hydroperiod, and amphibian species richness: implications for wetland regulations. Conservation biology, 2000, vol. 14, no. 2, pp. 414-419.

Todd B. D., Scott D. E., Pechmann J. H. K., Gibbons J. W. Climate change correlates with rapid delays and advancements in reproductive timing in an amphibian community. Proceedings of the Royal Society B: Biological Sciences, 2011, vol. 278, no. 1715, pp. 2191-2197.

Wells K. D. The ecology and behavior of amphibians. Chicago, The University of Chicago Press, 2007. $1162 \mathrm{p}$.

Yermokhin M. V. Ekologicheskaya struktura marginalnykh uchastkov rechnykh biotsenozov $v$ perekhodnoy zone voda - susha [Ecological Structure of Marginal Patches of River Biocenoses in Water - Land Transitional Zone]. Diss. Cand. Sci. (Biol.). Saratov, 2000. 192 p. (in Russian).

Yermokhin M. V. Methods for Studiing the Flows of Matter and Energy Formed by Animals between Aquatic and Terrestrial Ecosystems in the River Valleys. Ecosystems of Small Rivers: Biodiversity, Ecology, Conservation. Proceedings of lectures of II All-Russia School-Conference. Yaroslavl, Filigran Publ., 2014, vol. 1, pp. 42-56 (in Russian). 


\section{STRUCTURE TRANSFORMATION OF THE ANURAN AMPHIBIAN}

Yermokhin M. V., Tabachishin V. G. Reproductive Parameters of Females Pelobates fuscus (Laurenti, 1768) as Functions of Size and Weight Characteristics. Current Studies in Herpetology, $2011 a$, vol. 11, iss. 1-2, pp. 28-39 (in Russian).

Yermokhin M. V., Tabachishin V. G. Abundance Accounting Result Convergence of Pelobates fuscus (Laurenti, 1768) Migrating Toadlets at Full and Partitial Enclosing of Spawning Waterbody by Drift Fences with Pitfalls. Current Studies in Herpetology, 2011 b, vol. 11, iss. 3-4, pp. 121-131 (in Russian).

Yermokhin M. V., Tabachishin V. G., Ivanov G. A. Optimisation of Method of Amphibians Accounting by Drift Fences with Pitfalls. In: Problems of Marginal Structures of Biocenoses Investigations. Saratov, Izdatelstvo Saratovskogo universiteta, 2012, pp. 157-163 (in Russian).

Yermokhin M. V., Ivanov G. A., Tabachishin V. G. Spawning Migration Phenology of Anuran Amphibians in the Medveditsa River Valley (Saratov Region). Current Studies in Herpetology, 2013, vol. 13, iss. 3-4, pp. 101-111 (in Russian).

Yermokhin M. V., Tabachishin V. G., Ivanov G. A. Spawning migration phenology of the spadefoot toad Pelobates fuscus (Pelobatidae, Amphibia) in the valley of the Medveditsa River (Saratov Oblast). Biology Bulletin, 2015, vol. 42, no. 10, pp. 931-936.

Yermokhin M. V., Tabachishin V. G., Ivanov G. A. Long-term Dynamics of the Size-Weight and Sexual Structure in Populations of Pelobates fuscus (Anura, Pelobatidae) in the Medveditsa River Valley (Saratov Region). Current Studies in Herpetology, 2016, vol. 16, iss. 3-4, pp. 113122 (in Russian).

Yermokhin M. V., Tabachishin V. G., Ivanov G. A. Phenological changes in the wintering of Pelobates fuscus (Pelobatidae, Amphibia) in the climate transformation conditions in the Northern Lower Volga Region. Biology Bulletin, 2017, vol. 44, no. 10, pp. 1215-1227.

Yilmaz N., Kutrup B., Çobanoğlu Ü., Özoran Y. Age determination and some growth parameters of a Rana ridibunda population in Turkey. Acta Zoologica Academiae Scientiarum Hungaricae, 2005, vol. 51, no. 1, pp. 67-74.

Zhelev Z., Arnaudov A., Boyadzhiev P. Colour polymorphism, sex ratio and age structure in the populations of Pelophylax ridibundus and Pseudepidalea viridis (Amphibia: Anura) from anthropogenically polluted biotopes in southern Bulgaria and their usage as bioindicators. Trakia J. Science, 2014, no. 1, pp. 1-12. 
Mikhail V. Yermokhin, Gleb A. Ivanov, Vasily G. Tabachishin

УДК 597.833(470.44)

\title{
ТРАНСФОРМАЦИЯ СТРУКТУРЫ НЕРЕСТОВЫХ СООБЩЕСТВ БЕСХВОСТЫХ АМФИБИЙ ПОЙМЕННЫХ ОЗЁР ДОЛИНЫ р. МЕДВЕДИЦА (САРАТОВСКАЯ ОБЛАСТЬ) В УСЛОВИЯХ МНОГОЛЕТНЕГО СНИЖЕНИЯ ВОДНОСТИ
}

\author{
М. В. Ермохин ${ }^{1}$, Г. А. Иванов ${ }^{1}$, В. Г. Табачишин ${ }^{2}$ \\ ${ }^{I}$ Саратовский национальный исследовательский государственный университет \\ имени Н. Г. Чернышевского \\ Россия, 410012, Саратов, Астраханская, 83 \\ E-mail:ecoton@rambler.ru \\ ${ }^{2}$ Саратовский филиал Института проблем экологии и эволюиии им. А. Н. Северияова РАН \\ Россия, 410028, Саратов, Рабочая, 24 \\ E-mail: tabachishinvg@sevin.ru
}

Поступила в редакцию 12.09.2018 г., после доработки 21.10.2018 г., принята 29.10.2018 г.

\begin{abstract}
Yermokhin M. V., Ivanov G. A., Tabachishin V. G. Structure Transformation of the Anuran Amphibian Spawning Communities in Floodplain Lakes of the Medveditsa River Valley (Saratov Region) under Conditions of Long-Term Reduction of Water Content [Ермохин М. В., Иванов Г. А., Табачишин В. Г. Трансформация структуры нерестовых сообществ бесхвостых амфибий пойменных озёр долины р. Медведица (Саратовская область) в условиях многолетнего снижения водности] // Поволжский экологический журнал. 2018. № 4. С. 404 - 417. DOI: https://doi.org/10.18500/1684-7318-2018-4-404-417
\end{abstract}

Проанализирована структура нерестовых таксоценозов бесхвостых амфибий в пяти пойменных озёрах в долине р. Медведица в 2009 - 2018 гг. В качестве модельных использовали два притеррасных озера (Лебяжье и Ко́блово) и три озера центральной поймы (Садок, Кругленькое и Черепашье). Установлена деградация популяций трех наиболее многочисленных видов, снижение степени доминирования чесночницы обыкновенной. Деградации в большей степени подвержены виды с большей дистанцией нерестовых миграций - выраженность изменений последовательно убывает в ряду видов: Pelophylax ridibundus $\rightarrow$ Pelobates fuscus $\rightarrow$ Bombina bombina. Показатели структуры сообществ амфибий в притеррасных озёрах Лебяжье и Коблово были стабильны. На фоне малой водности и нестабильного гидрологического режима озёр центральной поймы с продолжительностью исследования пять и более лет были установлены три периода, характеризующих структуру нерестовых таксоценозов амфибий: стабильной структуры, резкого снижения доминирования и увеличения выравненности, увеличения вариабельности основных показателей структуры. В конце третьего периода, характеризующего структуру таксоценозов, отмечена некоторая стабилизация основных параметров при крайне низком уровне численности половозрелых особей всех видов амфибий. Высокий уровень весеннего половодья р. Медведица в 2018 г. определил начало выхода из аномально продолжительного периода малой водности нерестовых озёр в пойме (с 2009 по 2017 г.) и их функционирования в режиме временных водоёмов.. Произошедшее резкое увеличение водности пойменных озер и удлинения их гидропериода позволяет констатировать начало 


\section{STRUCTURE TRANSFORMATION OF THE ANURAN AMPHIBIAN}

процесса восстановления численности популяций и структуры сообществ бесхвостых амфибий.

Ключевые слова: Anura, Pelophylax ridibundus, Pelobates fuscus, Bombina bombina, нерестовый таксоценоз.

DOI: https://doi.org/10.18500/1684-7318-2018-4-404-417

Благодарности. Работа выполнена при частичной финансовой поддержке Российского фонда фундаментальных исследований (проект № 16-04-01248) и плановой научной темы (проект № 0109-2018-00010). 